\title{
REGULATION OF SECURITIES BY THE FEDERAL TRADE COMMISSION
}

\author{
FRED RODELL $\dagger$
}

The Federal Securities Act was passed to protect individuals from losing their money by investing it in unsoundly or unscrupulously financed business enterprises. ${ }^{1}$ If the bald statement amounts to a truism, that fact is not made apparent by the oral and written discussion which the Act has provoked. ${ }^{2}$ Informed by that discussion alone, the layman might as readily suppose that the Act was intended to harass innocent dealers in securities and drive honest investment bankers out of business. For discussion of the Act has crowded around the provisions for civil liability, ${ }^{3}$ in the nude. Unclothed by judicial interpretation, unhampered by application to a definite set of facts, these provisions have appeared as bogey-man. ${ }^{3 a}$ Financial leaders and the lawyers who work for them, anxious to see those provisions restricted, have blown them up to impossible proportions, and have read into them in the abstract such meanings as they themselves would be the first to discredit in the particular. ${ }^{4}$

$\dagger$ Assistat Professor of Law, Yale University.

More than the customary acknowledgment is due to John Gates, of the third year class in the Yale School of Law, without whose assistance this article would not have been written.

1. The simplicity of this statement does not signify unawareness of the fact that what the Act literally dqes is to afford publicity to the pertinent facts concerning a security issue, and thus presumably enable the investor to judge its worth. It is true that the average investor may make use of this opportunity only indirectly, in accepting the financial advice of his banker or broker who will make the actual judgment on the facts divulged. It is also true that the Act imposes remedial and punitive penalties on those responsible for false or misleading publicity. Nevertheless, the essential purpose of the Act, whether accomplished actively or passively, directly or indirectly, is to protect investors.

2. Cf. The Wall St. Journal, Nov. 6, 1933, at 1; id. Oct. 31, 1933, at 6; (1933) 137 Commr. and Fin. Chron. 254; id. at 3241; (1933) 21 Natron's Busnness 39; Wherry, The New Federal Securities Act (1933) 12 Puв. UTIL. Forr. 123; Dean, The Federal Securities Act (1933) 8 (2) Fortune 50; Business Week, July 8, 1933, at 14; U. S. News, Aug. 26at $27 ;$ N. Y. Herald Tribune, Sept. 11, 1933, at 6.

3. P. L. No. 22, 73d Cong., 1st Sess. (1933) §§ 11, 12. For analysis, see ThORPE AND

3. P. L. No. 22, 73d Cong., 1st Sess (1933) §§ 11, 12. For analysis, see ThoRpe AND Ellis, Manual of the Federat Securrties Act (1933) 92-113.

3a. Cf. The Securities Act: An Interim Report (1933) 8 (6) ForTune 34, 137, commenting upon ". . . the truly fanciful interpretations which a few highly erudite lawyers have built up, like so many scarecrows, from the somewhat ambiguous phrases of the law."

4. See F. M. Gordon, president of the Investment Banker's Association, in Wall St. Journal, Oct. 31, 1933, at 1: "Ail over the United States corporations are ready to undertake the necessary financing, but no corporation director in his senses is going to risk 
Whatever the merit of this discussion, however genuine these fears may be, attention has been effectively steered away from the basic purpose of the Act. ${ }^{\bar{j}}$ That purpose is to prevent before curing; to protect before punishing. ${ }^{6}$ And no matter how great the deterrent effect of the fear of civil liability, it is significant that beforehand protection of investors is not left to that fear alone. The Act provides a definite method of affirmative protection. Only when that protection fails will civil liability be invoked. Only to the extent that it fails can fear of liability act as a deterrent. That protection is embodied in the power of the Federal Trade Commission to issue and enforce stop orders against the sale of improperly registered securities. ${ }^{7}$

existing resources by putting his name on financing under a law that makes him personally liable for the next ten years and adopts the un-American principle that he is to be judged guilty unless he can be proven innocent." See also A. V. Godsave, vice-president and trust officer, Pacific National Bank of Seattle, (1933) 137 Connr. AND FIN. CHron. 3241; Arthur Dean of Sullivan and Cromwell in N. Y. Times, Oct. 15, 1933, IX-3, and in (1933) 8 (2) Fortune 102-106; Philadelphia Public Ledger, Oct. 17, 1933, at 19.

5. Commissioner Landis in an address before the N. Y. State Society of Certified Public Accountants, Oct. 30, 1933, said: "The Commission's powers of regulation have been rarely emphasized in any discussion of the Act and to my mind they are of great consequence. ... I make these remarks on the Commission's powers of regulation and interpretation not for the sake of emphasizing the powers as such but to illustrate the flexibilities inherent in the Act and its capacities for adaptation to the complexities of the situations it covers. Indeed, if half the energy that has been expended in fulminating against the Act and propagandizing for amendments were enlisted in the effort to advise the Commission in the wise exercise of its powers, the government and issuers, bankers, lawyers, and accountants would be far nearer to a solution of their problems." (1933) 137 Cosar. AND Fry. Chron. 3243.

6. President Roosevelt in his message to Congress said: "The purpose of the legislation I suggest is to protect the public with the least possible interference to honest business." See Hearings on H. R. 4314, 73d Cong., 1st Sess. (1933) at 1. The Act itself is entitled: "To provide full and fair disclosure of the character of securities sold in interstate and foreign commerce and through the mails, and to prevent frauds in the sale thereof, and for other purposes."

7. $\S 8$ :

"(b) If it appears to the Commission that a registration statement is on its face incomplete or inaccurate in any material respect, the Commission may, after notice . . . and opportunity for hearing ..., issue an order prior to the effective date of registration refusing to permit such statement to become effective until it has been amended in accordance with such order. When such statement has been amended in accordance with such order the Commission shall so declare and the registration shall become effective at the time provided in subsection (a) or upon the date of such declaration, whichever date is the later.

"(c) An amendment filed after the effective date of the registration statement, if such amendment, upon its face, appears to the Commission not to be incomplete or inaccurate in any material respect, shall become effective on such date as the Commission may determine, having due regard to the public interest and the protection of investors.

"(d) If it appears to the Commission at any time that the registration statement includes any untrue statement of a material fact required to be stated therein or necessary to make the statements therein not misleading, the Commission may, after notice... 
The stop order is the first line of defense against bad security issues. It can and should become the main line of defense. Direct recourse to the courts for injunction ${ }^{8}$ or mandamus, ${ }^{9}$ such as is granted the Commission, should be needed only rarely,- to put teeth into a disobeyed stop order or to spike a flagrant violation of the Act.

Moreover, the importance of the Commission's issuing or, conversely, its failure to issue a stop order can not be overestimated in its effect on subsequent civil or criminal suits arising from the sale of registered securities. Despite insistence by the Commission, ${ }^{10}$ by Congress, ${ }^{11}$ and by President Roosevelt ${ }^{12}$ that registration under government supervision does not amount to a guarantee of the security, such registration can not help but amount to a guarantee of immunity to those connected with the issue who have neither consciously nor carelessly allowed material facts to be misstated nor consciously allowed material facts to be omitted. Whether or not approval of the scope of a registration by one branch of the government, the Commission, might estop another branch of the government, the courts, from later recording disapproval in the form of a liability judgment, as a member of the Commission has suggested ${ }^{13}$ it is at least certain that Commission acquiescence in a registration statement will weigh almost conclusively in favor of a defendant charged with neglect to include in the statement facts about which he had no special knowledge. In short, where the "materiality" of an

and after opportunity for hearing ...., issue a stop order suspending the effectiveness of the registration statement. When such statement has been amended in accordance with such stop order the Commission shall so declare and thereupon the stop order shall cease to be effective."

Subsection (e) empowers the Commission to make an examination in order to determine whether a stop order shall issue under subsection (d).

8. $\$ 20$ (b).

9. $\$ 20$ (c).

10. Federal Trade Commission, Rules and Regulation under the Securities Act (1933) art. 16, requires the following statement in every prospectus: "Neither the fact that such registration statement has been filed with the Commission, nor the issuance of the prospectus under the rules or regulations prescribed, shall be deemed a finding by the Commission that this prospectus is true and accurate on its face, or omits to state a material fact or to mean that the Commission has in any way passed upon the merits of, or given approval to, such prospectus or the security mentioned therein."

11. The House Committee on Interstate and Foreign Commerce stated in its report, H. R. Rep. No. 85, 73d Cong. Ist Sess. (1933) at 3: "In brief, the aims set forth by the President are: . . . (2) A requirement that whatever action taken by the Federal Government for such disclosure should be limited to that purpose and should be so devised as not to be capable of being construed as an approval or guarantee of a security issue. . . The achievement of these ends is the principal purpose of this bill."

12. President Roosevelt in his message to Congress, supra note 6, said: "Of course, the Federal Government cannot and should not take any action which might be construed as approving or guaranteeing that newly issued securities are sound in the sense that their value will be maintained or that the properties which they represent will earn profit."

13. Landis, supra note 5. 
omission is concerned-and it is about this point that much of the persecution cry has been raised, ${ }^{14}$ - no court is likely to expect an otherwise blameless individual to be a better guesser than the Commission itself.

Thus, in the absence of carelessness about ascertainable facts or a downright intention to deceive on the part of those responsible for a security issue, such protection as the Act affords investors hinges on the ability and alertness of the Commission in supervising registration of securities. ${ }^{15}$ It is for the Commission also to catch misstatements and frauds whenever possible. But in the short space of time ${ }^{16}$ allotted the Commission for investigation, concealed inaccuracies and clever deceit will often slip through undetected. It is in such instances and such instances only, where affirmative protection fails, that the curative rights of investors and the punitive power of the government will come into play. In day-to-day practice, and with respect to the overwhelming majority of securities issued, the effectiveness of the Act will depend directly on the able use of the stop order by the Commission.

14. See articles cited note 2, supra. In the Wall St. Journal, Oct. 31, 1933, at 1-2, F. M. Gordon, president of the Investment Bankers Association, asserts that inclusion of absolutely all facts with respect to any issue in a prospectus is impossible and that an apparently trivial point omitted therefrom may in the light of later events turn out to be of material importance and subject each banker and corporation to civil and criminal liability. Landis, supra note 5, at 3242 , in discussing such objections, indicates that such fear seems unfounded inasmuch as the materiality is undoubtedly to be determined in view of the circumstances at the time of registration.

15. Such alertness has to date been clearly demonstrated. Some $\$ 319,500,000$ worth of securities had been filed for registration with the Commission up to Nov. 8, 1933. By Oct. 28, 1933, eleven stop orders had been issued in the following cases: (1) Speculative Investment Trust for failing to file a copy of proposed prospectus, not having proper certification of its balance sheet, and for incorrect statements as to shares outstanding; (2) American Gold Mines Consolidation, Inc., for omissions in balance sheet, improper certification, and confusion as to shares already subscribed exceeding the amount registered for issuance; (3) Industrial Institute, Inc., for general deficiencies in its statement; (4) Transcontinental Precious Metals Corp. for failure to make prospectus show essential features set forth in registration data; (5) Southern Crude Oil Co. for omission to file balance sheet, profit and loss statement, and prospectus; (6) Liberty Brewing Co. for failure to include in prospectus some essential features of registration statement; (7) Byron Gold Mining Co. for omission of certification, incomplete prospectus, and incomplete statement of shares authorized; (8) Southwestern Trading Co. for failure to state underwriter's commission, to name executive officers, and to make prospectus "tie up" with registration statement; (9) Golden West Mining Co. for discrepancy in assets and liabilities, incomplete profit and loss statement, and lack of certification; (10) Shamrock Gold Mining Co. for incomplete report as to interests of officers, directors, and underwriters in property acquired and failure to name donor of treasury stock; (11) Van Cortlandt Recreation Corp. for incomplete report of interest of President in property acquired, for confusion of balance sheet items, and failure to report purposes of security offered. (1933) 137 Conrar. AND Fin. Chron. 1341, 1519, 1706, 2391, 3084, 3245.

16. The Act provides for a twenty-day period after filing before the registration statement becomes effective. $\$ 8$ (a). 
Over the head of the Commission, however, hangs a perpetual sword of Damocles in the power of the courts to review. ${ }^{17}$ If the enforcement of the Act rests with the Commission, the efficacy of that enforcement rests just as surely with the courts, in the tolerance with which they come to regard the Commission's regulations and orders.

The courts which first review the Commission's orders will not be working wholly without benefit of precedent. Government control of security issues is not new. Moreover most of the state Blue Sky laws are set up and administered along the same line as the Federal Securities Act. ${ }^{18}$ Under most of them, although the field of regulation is more limited, ${ }^{19}$ there is the same preliminary control of specific security issues, the same privilege of investigation, the same power to prohibit the sale of questioned issues. ${ }^{20}$ Some of these state statutes allow the commissions entrusted with their enforcement even broader discretionary powers than are granted under the federal Act. ${ }^{21}$ Stop orders may be issued

17. $\$ 9$ (a).

18. Forty-seven states have Blue Sky laws. Three of these statutes are punitive in nature, while the remainder are preventive. Most of the latter have provisions to control the sale of specific issues of securities by either qualification or notification, or both. Qualification provides for approval and sale only after a preliminary investigation similar to that required by the Federal Securities Act. Administration by qualification has proved to be limited for two reasons: (1) the delays of preliminary approval are often so onerous that bankers avoid selling in such states; (2) in a number of states requiring qualification, modification of the terms of an issue permit it to be registered by notification instead and this makes the issue effective on filing, with a power of stop order remaining in the commission to be exercised when deemed advisable. See Perrin, The Blue Sky Laws (1916) 48 Chicago L. News 327, 332; Brach, The Blue Sky Law (1919) 3 Marquetre L. Rev. 142; Wham, Rights under Blue Sky Laws (1925) 15 A.B.A.J. 310; Meeker, Preventive v. Punitive Security Laws (1926) 26 Cor. L. REv. 318; Thormodsgard, Mriddle West Blue Sky Legislation (1927) 1 DAK. L. Rev. 138; Ashby, Operation of the Blue Sky Laws (1927) 1 Tentrie L. Q. 103; Dalton, Development and Future Trends in State Security Regulation (1933) 12 HARv. Bus. Rev. 23; Edwards, Control of the Security Investment System (1933)

12 id. 87; ReEd and WashBuRN, Blue Sky Laws (1921).

19. Cf. Montgondery, Financial Handbook (1933) 1173. In general the statutory exemptions include: (1) securities of state, federal, or municipal governments; (2) enterprises already subject to regulation; (3) issues listed on the New York Stock Exchange; (4) issues rated highly by financial manuals; (5) issues meeting certain tests of earning power; (6) most real estate mortgage bonds and notes; (7) short term issues of less than a year.

20. See 2 Commerce Clearing House, Stocks and Bonds Law Service, for state statutes; UnIform SAIE of SeCURITIES ACT \& 8; MontGoMiery, op. cit. supra note 19, at 1172.

21. CaI. Gen. Laws (Deering, 1931) Act 3814, $\$ 4$ ("If he finds that the proposed plan - of business of the applicant is not unfair, unjust, or inequitable, that it intends to fairly and honestly transact its business ..."); 2 MrCE. Cosrp. LAws (1929) $\$ 9780$ (permission shall not be granted where it appears to the commission ". . . that the proposed disposal of securities is on unfair terms"); Wis. Laws 1933, c. 158, \& 189.07 ("If the proposed plan of business of the issuer is not unlawful, dishonest, fraudulent, or otherwise contrary to public policy; the plan of financing is not unfair, inequitable, dishonest, or fraudulent ... otherwise it shall issue its . . . order denying the application."). 
for any reason which the controlling board deems consonant with the public interest. ${ }^{22}$

Yet even where the powers granted are so broad as perhaps to justify the judicial fear of bureaucratic government, the courts have not tried to restrict the commissions in their control of intrastate security transactions under the Blue Sky laws. ${ }^{23}$ There has been a definite reluctance to interfere with administrative decisions unless clearly arbitrary or beyond the scope of the regulatory power. ${ }^{24}$ The mere fact that, according to the board's judgment, the contemplated business venture did not have much chance of success has been held sufficient cause to warrant a stop order against the sale of securities. ${ }^{25}$ This judicial attitude of tolerance was well expressed by the Supreme Court of Minnesota when it said: ${ }^{20}$

"In view of the ingenuity of those who seek to induce men and women to put their money into far-off speculative enterprises over which the investor has little or no control, and in view of the paternalistic character of Blue Sky Laws, it should be the policy of the courts to refrain from hampering the State officials in the performance of their duties by placing a narrow construction on such laws."

Again, where state utility commissions are granted control of utility securities, ${ }^{27}$ the courts have been loath to disturb commission findings

22. Note 21, supra. See also Wis. Laws 1933, c. $158, \S 189.14$.

23. Cf. Investment Reserve Corp. v. Michigan Securities Commission, 238 Mich. 606, 214 N. W. 311 (1927) (refusal to disturb commission order "unless the evidence is overwhelmingly convincing to the contrary") ; Pacific Home Building Realty Co. v. Daugherty, 75 Cal. App. 623, 243 Pac. 473 (1925) (Commissioner utterly free from any check or interference by means of writ of review. "If he reaches an incorrect conclusion on that matter, it is obvious to us that his determination is merely error.").

24. See G. F. Redmond and Co. v. Michigan Securities Commission, 222 Mich. 1, 192 N. W. 688 (1923) ; Co-operative Farm Loan Co. v. Hirning, 40 S. D. 448,167 N. W. 1055 (1918); cases cited note 23, supra. See Gross and Brown, Adninistrative Powers Under Blue Sky Laws (1931) 16 St. Louss L. Rev. 141; Robertson, Adninistrative Control over Security Issues in Nebraska (1932) 11 NEB. L. BuLr. 116; Note (1932) 12 B. U. L. REv. 563 .

The authority of commissions to impose conditions is upheld in Basalt Rock Co. v. Macmillan, 80 Cal. App. 147, 251 Pac. 322 (1926); Leach v. Daugherty, 73 Cal. App. 83, 238 Pac. 160 (1925).

25. State ex rel. Hardstone Brick Co. v. Department of Commerce, 174 Minn. 200, 219 N. W. 81 (1928) ; Doble Steam Motors Corp. v. Daugherty, 195 Cal. 158, 232 Pac. 140 (1924); Hayden Plan Co. v. Friedlander, 97 Cal. App. 12, 275 Pac. 253 (1929); Dominiguez Land Corp. v. Daugherty, 196. Cal. 453, 238 Pac. 697 (1925) ; Home Lumber Co. v. State Charter Board, 107 Kan. 153, 190 Pac. 601 (1920).

26. Kerst v. Nelson, 171 Minn. 191, 195, 213 N. W. 904, 905 (1927).

27. Twenty-five states permit some kind of regulation of security issues by their public service commissions. See Waltersdorf, State Control of Utility Capitalization (1927) 37 YALE L. J. 337; Rosenbaum and Lilienthal, Issuance of Securities by Public Service Corporations (1928) 37 YaLE L. J. 716, 906; Rosenbaum, Regulation of Security Issues by the Ohio 
and regulations. ${ }^{28}$ This fact is especially significant in the light of the extensive control exerted by the courts and the correspondingly restricted discretion allowed to the same commissions in questions of rate regulation. $^{29}$ And in the Federal field, the somewhat limited jurisdiction of the Postmaster-General over the sale of fraudulent securities through the mails has on review been liberally treated by the courts. ${ }^{30}$

In direct contrast to these lines of precedent setting a liberal standard for the judicial review of administrative security regulation, stands the record of the federal courts in reviewing Federal Trade Commission orders in the past. The paternal supervision exercised over the Commission in its regulation of unfair trade practices has been too often noted to need substantiation here. ${ }^{31}$ Purporting to hold the Commission within its statutory powers, the courts have in effect substituted their own judgments at will for those of the Commission's experts, to the point of

Public Utilities Commission (1930) 4 CINN. L. Rev. 321; Comment (1933) 7 TenmLe L. Q. 353 .

28. Cf. Pollitz v. Public Utilities Commission, 97 Ohio St. 191, 119 N. E. 507 (1918); Interstate Telephone and Telegraph Co. v. Board of Public Utility Commissioners, 84 N. J. L. 184, 86 Atl. 363 (1913); Hillsdale Light and Fuel Co. v. Michigan Public Utilities Commission, 220 Mich. 101, 189 N. W. 893 (1922); Public Service Commission v. City of Indianapolis, 193 Ind. 37, 137 N. E. 705 (1922); Fall River Gas Works Co. v. Board of Gas and Electric Light Commissioners, 214 Mass. 529, 102 N. E. 475 (1913); United States and Mexican Trust Co. v. Deleware Western Construction Co., 112 S. W. 447 (Tex. Civ. App. 1908). But the commission cannot by its exercise of discretion control the activities of business enterprise. See Kansas City Kaw Valley and Western Ry. Co. v. Bristow, 101 Kan. 557, 562, 167 Pac. 1138, 1140 (1917); People ex rel. The Delaware and Hudson Co. v. Stevens, 197 N. Y. 1, 10, 90 N. E. 60, 63 (1909).

29. See Mosher and Crawford, Public Utility Regulation (1933) 52.

30. See 26 Stat. 466 (1890), 39 U. S. C. \$\$ 259, 732 (1926). The Postmaster may issue "stop orders" forbidding the delivery of mail or money orders in connection with "any scheme or device for obtaining money or property of any kind, through the mails, by means of false or fraudulent pretences, representations or promises." That this applies to fraudulent investment schemes see Public Clearing House v. Coyne, 194 U. S. 497 (1904); People's United States Bank v. Gilson, 161 Fed. 286 (C. C. A. 8th, 1908); 23 OP. ATT'y Gen. 512 (1901). The Postmaster General has been allowed a broad exercise of discretion under this "stop order" power. In Appleby v. Cluss, 160 Fed. 984, 985 (C. C. D. N. J. (1908), the court said: "A federal court will not weigh the facts adduced before the Postmaster General in order to determine whether the court's judgment on the facts will accord with his. It will only look into those facts for the purpose of determining whether, in any aspect of the case, they are covered by any act of Congress or support a conclusion of fraud." Cf. also Bates and Guild Co. v. Payne, 194 U. S. 106 (1904); Leach v. Carlisle, 258 U. S. 138 (1922).

31. See, e.g., McFarland, Judrclal Control of the Federar Trade Commission and the Interstate Contacerce Conramssion 1920-1930 (1933); Henderson, Tee Federax Trade Commasston (1924) 98 et seq. Tollefson, Judicial Review of the Decisions of the Federal Trade Commission (1927) 4 WIs. L. Rev. 257; Comment (1930) 4 Tulane L. REv. 638; International Shoe Co. v. Federal Trade Commission, 280 U. S. 291 (1930). 
emasculating the administrative body in the performance of what it reasonably conceived to be its proper duties. ${ }^{32}$

It is true that this paternalism relaxed a bit as trade regulation left its formative stage. The courts came to give more weight to Commission findings, ${ }^{33}$ perhaps from a feeling that their ward had grown older. But through the technique of the earlier decisions, the courts still hold and too readily exercise ${ }^{34}$ a whiphand over the Commission. The danger is a live one that this same technique and this same unwillingness to concede responsibility to the Commission may be carried over to the securities field, particularly in view of the novelty of federal control. Nor would it be difficult for the courts to discover legalistic justification for hamstringing the Commission in its effective use of the stop order. The legislative hope that the Commission's findings of fact "shall be conclusive," ${ }^{35}$ almost identical to that embodied in the Clayton Act, ${ }^{36}$ could be qualified out of existence. At the utmost extreme, an application of the principle enunciated by the Supreme Court in Crowell v. Benson ${ }^{37}$ -that "fundamental" or "jurisdictional" facts demand a court determination-might be held to subject to judicial review de novo every Commission finding contributing to the issuance of a stop order, and might thus leave the Commission without a vestige of discretion, power, or usefulness under the Act.

Yet when the cases actually come to court, neither the liberal nor the strict line of precedent will or should be controlling. The regulation of securities by the Federal Trade Commission is an entirely different thing from the regulation of securities by other commissions and from the regulation of other matters by the Trade Commission. With the doors of analogous precedent open to either choice, a display of tolerance and a granting of leeway to the body entrusted with the major task of enforcing an important piece of social legislation seems, without question, the wiser judicial course.

In encouraging the courts to refrain from interfering with the administrative work of security regulation and to assist, by upholding, a practical enforcement of the Act, a large share of the opportunity and

32. Cf. Comment (1930) 4 Tulane L. Rev. 638.

33. Cf. Hill Bros. v. Federal Trade Commission, 9 F. (2d) 481 (C. C. A. 9th, 1926) ; Moir v. Federal Trade Commission, 12 F. (2d) 22 (C. C. A. 1st, 1926); Arkansas Wholesale Grocers' Association v. Federal Trade Commission, 18 F. (2d) 866 (C. C. A. 8th, 1927).

34. Cf. International Shoe Co. v. Federal Trade Commission, supra note 31, holding that under the Clayton Act the courts must have the power to examine the whole record, ascertain the issues presented, and determine whether there are any material facts not reported by the Commission, since the statute grants jurisdiction to make and enter upon the pleadings, testimony and proceedings, a decree affirming, modifying, or setting aside an order.

35. § 9 (a).

36. 38 StaT. 719 (1914), 15 U. S. C. $\$ 45$ (1926).

37. 285 U. S. 22 (1932); see Comment (1932) 41 YALE L. J. 1037. 
responsibility reverts to the Commission itself. The more ably it supervises the issuing of securities, the less excuse the courts will find to overturn its decisions. So from the Commission's initial task of carrying on its shoulders the affirmative protection of the investing public under the Act, the circle returns again to the Commission, leaving to it the correlative burden of persuading the courts not to interfere with a job well done.

This importance of the Commission in the protective scheme will become more and more apparent as time goes on. Such amendments to the present statute as have been suggested or contemplated would not narrow the broad scope of the Commission's power. Most of them seek to limit or define more closely the liabilities imposed by way of backhand protection, ${ }^{38}$ and it is the furore raised in behalf of these which has created in the public mind a warped impression of just what the Act purposes to do. Among the more thoughtful and less prejudiced proposals is one which would give the Commission original jurisdiction of civil liability suits arising under the Act and thus complete the Commission's cycle of direct responsibility. ${ }^{39}$ After the changes have been made and the courts have read law into the disputed phrases-after the adolescent years have passed-the flexible day-to-day control of security issues will still rest, curiis volentibus, with the Commission alone.

The Federal Securities Act was passed to protect individuals from losing their money by investing it in unsoundly or unscrupulously financed business enterprises. If this be truism, may the Commission, the courts, and the commentators make the most of it.

39. See Douglas and Bates, The Federal Securities Act of 1933 (1933) 43 YALE L. J. 171, 215. 